JAMP: Jurnal Adminitrasi dan Manajemen Pendidikan Volume 1 Nomor 1 Maret 2018, Hal : 79-86

Tersedia Online di http://journal2.um.ac.id/index.php/jamp/ ISSN $x x x x-x x x x$ (online)

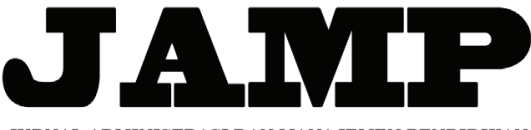

JURNAL ADMINISTRASI DAN MANAJEMEN PENDIDIKAN

\title{
HUBUNGAN KOMPETENSI DAN MOTIVASI KERJA DENGAN KINERJA TENAGA ADMINISTRASI SEKOLAH
}

\author{
Rossa Valentina \\ Maisyaroh \\ Desi Eri Kusumaningrum
}

email: rossavalentina04@gmail.com

Universitas Negeri Malang, Jl. Semarang No. 5 Malang 65145

\begin{abstract}
The research is done to describe the level of competency of school administrative staff, describe the level of work motivation of school administrative staff, describe the level of performance of school administrative staff, and understand the connection of competency and work motivation with the performance of the school administrative staff. The approach of this study is quantitative that is correlation descriptive research with 111 respondents. As forcollecting data is questionnaire. The results of the research show that the competency of school administrative staff is high, the work motivation of school administrative staff is high, the performance of school administrative staff is high, and there is a relationship of competency and work motivation with performance of school administrative staff.
\end{abstract}

Keywords: competency, work motivation, performance

\begin{abstract}
Abstrak: Tujuan penelitian ini untuk mendeskripsikan tingkat kompetensi tenaga administrasi sekolah, mendeskripsikan tingkat motivasi kerja tenaga administrasi sekolah, mendeskripsikan tingkat kinerja tenaga administrasi sekolah, serta mengetahui hubungan kompetensi dan motivasi kerja dengan kinerja tenaga administrasi sekolah. Penelitian ini menggunakan pendekatan kuantitatif dengan rancangan deskriptif korelasional, dengan 111 orang responden. Hasil penelitian menunjukkan bahwa kompetensi tenaga administrasi sekolah tergolong tinggi, motivasi kerja tenaga administrasi sekolah tergolong tinggi, kinerja tenaga administrasi sekolah tergolong tinggi, dan terdapat hubungan kompetensi dan motivasi kerja dengan kinerja tenaga administrasi sekolah.
\end{abstract}

Kata kunci: kompetensi, motivasi kerja, kinerja

Sumber Daya Manusia (SDM) merupakan sumber aset suatu lembaga yang sangat berharga. Agar dapat memberikan kontribusi yang optimal, seharusnya SDM dikelola dengan baik. SDM merupakan makhluk sosial yang kompleks, dimana dapat memberikan pengaruh positif maupun negatif bagi suatu lembaga. Sebuah lembaga dituntut untuk mengelola dan mendayagunakan secara produktif SDM yang ada di dalamnya.

Sumber Daya Manusia pada lembaga pendidikan terdiri atas pendidik dan tenaga kependidikan. Sebagaimana yang tertera dalam Undang-Undang Nomor 20 Tahun 2003 tentang Sistem Pendidikan Nasional Pasal 39 Ayat 1 "tenaga kependidikan bertugas melaksanakan administrasi, pengelolaan, pengembangan, pengawasan, dan pelayanan teknis untuk menunjang proses pendidikan pada suatu pendidikan". Tenaga Administrasi Sekolah (TAS) merupakan bagian dari tenaga kependidikan yang menangani bidang administrasi. Tenaga administrasi sekolah mempunyai peran yang sangat penting di dalam sebuah lembaga pendidikan. TASmerupakan tenaga kependidikan yang bertugas memberikan dukungan layanan administrasi guna terselenggaranya proses pendidikan di sekolah. 
Sebuah lembaga pendidikan yang bermutu harus memiliki manajemen yang efektif. Peningkatan kinerja dapat dilakukan dengan cara mendukung pegawai agar memiliki kompetensi kerja yang tinggi. Rendahnya kompetensi yang dimiliki oleh pegawai dapat mengakibatkan kinerja mereka menurun. Kinerja dapat dilihat dari seberapa besar mereka bekerja secara tepat, cermat, efektif dan efisien. Usaha dalam meningkatkan kompetensi dan motivasi kerja akan menghasilkan kerja TAS yang tinggi, sehinggadengan mudah dapat meningkatkan kinerja TAS. Namun hal tersebut terkadang tidak berjalan seperti yang diharapkan, karena adanya hambatan TAS dalam mencapai kinerja yang tinggi. Hal ini disebabkan oleh kurang percaya diri, kurang mandiri, skill yang belum memadai, motivasi diri yang yang belum dapat melepaskan pola struktural artinya melaksanakan kegiatan didasarkan atas instruksi atau deskripsi tugas struktural. Hal sepertiinilah yang menjadi indikasi adanya penurunan kinerja sehingga berdampak pada perkembangan tenaga administrasi sekolah.

Faktor yang menyebabkan TAS termotivasi untuk bekerja produktif yaitu adanya keinginan setiap individu untuk mendapatkan kenaikan pangkat. Jadi dapat disimpulkan bahwa TAS selalu berupaya bekerja kerassecara produktif guna mencapai reward di sekolah. Akan tetapi sesuai pengamatan di lapangan yang dilakukan oleh Wahyudi (Dwidiyaningsih, 2011:4) menunjukkan bahwa: 1. masih banyak pegawai tata usaha yang belum atau bahkan memiliki kemampuan, kecakapan atau keahlian yang memadai untuk mengerjakan tugas-tugas mereka dengan performa yang baik dan memuaskan. Hal ini dapat dilihat dari masih banyak pegawai tata usaha yang belum bisa mengoperasikan komputer dengan baik untuk urusan administrasi tata usaha sekolah, padahal hampir semua urusan administrasi sekolah sekarang menggunakan komputer. Pekerjaan tata usaha sekolah masih semrawut, seperti pengarsipan surat yang tidak rapi, data-data sekolah yang tidak lengkap maupun tidak up to date; 2 . masih rendahnya disiplin, loyalitas dan tanggung jawab pegawai tata usaha dalam merencanakan dan melaksanakan tugas-tugas mereka sebagai pegawai tata usaha sekolah; 3 . masih belum tercerminnya pelayanan prima yang diberikan pegawai tata usaha kepada siswa, orang tua dan masyarakat; 4. masih belum nampaknya kecerdasan emosional, spiritual, dan bahkan juga kecerdasan intelektual pegawai tata usaha dalam memecahkan berbagai permasalahan serta dalam berinteraksi di lingkungan.

Banyak aspek internal maupun eksternal yang dapat mendukung terciptanya kinerja yang efektif dan efisien pada suatu organisasi. Hal-hal yang dapat mempengaruhi upaya peningkatan kinerja adalah kompetensi dan motivasi kerja. Kompetensi adalah "karakteristik dasar seseorang (individu) cara berfikir, dan bertindak yang berupa motif, karakter pribadi, konsep diri, pengetahuan serta keterampilan" (Ruky, 2003:104). Sedangkan menurut Mantja (2007:2), kompetensi adalah "kemampuan melaksanakan sesuatu yang diperoleh dari pendidikan dan atau pelatihan". Menurut Sedarmayanti (2009) "kompetensi kerja merupakan faktor kunci penentu bagi seseorang dalam menghasilkan kinerja yang sangat baik". Sehinggadapat disimpulkan bahwa tingkat kompetensi yang dimiliki seorang pegawai sangat berpengaruh terhadap suatu kinerja.

Hal ini sejalan dengan penelitian Nugraha (2013), yang berjudul "Hubungan Antara Kompetensi Kerja dengan Kinerja Karyawan PT Bukit Asam (Persero) Tbk", menunjukkan bahwa: 1. ada hubungan positif yang sangat signifikan antara kompetensi kerja dengan kinerja karyawan PT.Bukit Asam ( persero )tbk; 2. kompetensi berperan sebesar 73\% dan koefisien dterminan ( $\mathrm{r} 2)=0,730$ dalam mempengaruhi kinerja karyawan; 3. tingkat kinerja karyawan mengalami peningkatan pada setiap semesternya; 4. tingkat kompetensi karyawan dan kinerja karyawan tergolong baik dan sangat baik.

Pemenuhan kompetensi TAS wajib dipenuhi oleh penyelenggara sekolah, dimana kompetensi TAS berbeda dengan pendidik. Sesuai dengan Peraturan Menteri Pendidikan Nasional (Permendiknas) Nomor 24 Tahun 2008 tentang Standar Tenaga Administrasi Sekolah/ Madrasah. Tertuang dalam Pasal 1 Ayat 2 dijelaskan: "untuk dapat diangkat sebagai Tenaga Administrasi Sekolah/ Madrasah, seseorang wajib memenuhi standar Tenaga Administrasi Sekolah/Madrasah yang berlaku secara nasional”.

Sesuai dalam Permendiknas Nomor 24 Tahun 2008 tentang standar Tenaga Administrasi Sekolah/ Madrasah (TAS/ M), dimensi kompetensi yang harus dimiliki oleh Kepala TAS adalah kompetensi kepribadian, kompetensi sosial, kompetensi teknis, dan kompetensi manajerial. Dimensi kompetensi yang dimiliki oleh pelaksanaurusan dan petugas layanan khusus adalah kompetensi kepribadian, kompetensi sosial, dan kompetensi teknis. 
Selain kompetensi yang harus dimiliki oleh pegawai adalah motivasi kerja.Menurut Mathis dan Jackson (Umam, 2010), faktor- faktor yang mempengaruhi kinerja adalah "kompetensi, motivasi, dukungan yang diterima, keberadaan pekerjaan yang mereka lakukan, dan hubungan mereka dengan organisasi".Pemberian motivasi merupakan faktor yang menentukan dalam usaha meningkatkan kinerja pegawai. Oleh karena itu pimpinan harus mampu memberikan dorongan motivasi yang tepat serta memperlakukan pegawai sebagai manusia seutuhnya, hingga mereka akan merasa puas dan bekerja dengan baik. Motivasi kerja merupakan salah satu aspek yang sangat penting dalam menentukan perilaku seseorang termasuk perilaku kerja sebagaimana dikemukakan Rivai (2009:837): motivasi adalah serangkaian sikap dan nilai-nilai yang mempengaruhi individu untuk mencapai hal yang spesifikasi sesuai dengan tujuan individu. Sikap dan nilai tersebut merupakan suatu yang invisible yang memberikan kekuatan untuk mendorong individu bertingkah laku dalam mencapai tujuan. Dorongan tersebut terdiri dari komponen, yaitu: arah perilaku (kerja untuk mencapai tujuan), dan kekuatan perilaku (seberapa kuat usaha individu dalam bekerja).

Sedangkan Mangkunegara (2003:165) memberi pendapat mengenai motivasi yaitu: individu yang mempunyai motivasi tinggi cenderung memiliki prestasi kerja tinggi, dan sebaliknya mereka yang prestasi kerjanya rendah disebabkan karena motivasi kerja rendah. Oleh karena itu pimpinan organisasi harus berusaha keras mempengaruhi motivasi seluruh individu organisasi agar memiliki motivasi berprestasi tinggi. Dengan demikian pencapaian produktivitas pegawai dapat dicapai secara maksimal.

Hal ini sejalan dengan penelitian Rahmawati (2008), yang berjudul "Hubungan Motivasi Kerja dengan Kinerja Tenaga Administrasi Sekolah (TAS) padaSMA Negeri di Kota Malang", menunjukkanbahwa "hasil penelitian didapatkan nilai rhitung sebesar 0,493 (nol koma empat ratus sembilan puluh tiga). Dari keterangan tersebut maka dapat disimpulkan bahwa ada hubungan yang positif antara motivasi kerja dengan kinerja tenaga adminstrasi sekolahpada SMA Negeri di Kota Malang”.

\section{METODE}

Penelitian ini menggunakan pendekatan kuantitatif dengan rancangan penelitian deskriptifkorelasional. Dalam penelitian ini terdapat tiga variabel yang dikelompokkan menjadi dua, yaitu variabel bebas/independen dan variabel terikat/dependen.Variabel bebas dalam penelitian ini adalahkompetensi TAS (X1) dan motivasi kerja TAS (X2), sedangkan variabel terikat (Y) adalah kinerja TAS. Populasi pada penelitian ini adalah seluruh TAS SMA Negeri Se-Kabupaten Trenggalek yang terdiri dari 12 SMAN dengan 153 orang TAS. Dalam penelitian ini, teknik pengambilan sampel yang digunakan adalah Teknik Simple Random Sampling dan Proportional Random Sampling. Teknik pengambilan dan penentuan sampel yang digunakan pada masing-masing sekolah menggunakan Proportional Random Sampling. Jadi sampel yang diteliti adalah 111 orang TAS.

Teknik pengumpulan data menggunakan instrumen berupa kuesioner atau angket jenis tertutup karena telah disediakan jawaban sehingga responden hanya memilih salah satu alternatif jawaban. Pengukuran dalam penelitian ini dengan skala Likert 4 (empat) poin untuk mengurangi kecenderungan jawaban netral. Teknik analisis data pada penelitian ini menggunakan analisis deskripsi untuk mengetahui tingkat kompetensi TAS, motivasi kerja TAS, dan kinerja TAS yang dibagi menjadi 3 tingkatan, yaitu tingkat tinggi, sedang, dan rendah. Selanjutnya analisis korelasi Product Moment Pearson dimaksud untuk mengetahui derajat hubungan antara variabel $\mathrm{X}$ (kompetensi TAS dan motivasi kerja) dengan variabel Y (kinerja). Untuk mengetahui derajat hubungan antara variabel X1 (kompetensi TAS) dan X2 (motivasi kerja) dengan variabel Y (kinerja) digunakan analisis korelasi ganda (multiple correlation).

\section{HASIL}

\section{Analisis Deskriptif Variabel Penelitian}

Berdasarkan analisis yang telah dilakukan, diketahui bahwa kompetensi, motivasi kerja dan kinerja TAS dapat dilihat pada Tabel 1. 
Tabel 1 Analisis Deskriptif Variabel Penelitian

\begin{tabular}{cccccc}
\hline & \multicolumn{5}{c}{ Variabel } \\
\cline { 2 - 4 } Parameter & \begin{tabular}{c} 
Kepala \\
\cline { 2 - 4 }
\end{tabular} & $\begin{array}{c}\text { Pelaksana } \\
\text { Urusan }\end{array}$ & $\begin{array}{c}\text { Tenaga Layanan } \\
\text { Khusus }\end{array}$ & $\begin{array}{c}\text { Motivasi } \\
\text { (X1) }\end{array}$ & $\begin{array}{c}\text { Kinerja } \\
(Y)\end{array}$ \\
\hline N (sampel) & 12 & 64 & 35 & 111 & 111 \\
Mean & 193.75 & 157.92 & 158.14 & 105.60 & 65.04 \\
Kategori Rendah & $<124$ & $<100$ & $<100$ & $<66$ & $<40$ \\
Kategori Sedang & $<186$ & $<150$ & $<150$ & $<99$ & $<60$ \\
Kategori Tinggi & $\geq 186$ & $\geq 150$ & $\geq 150$ & $\geq 99$ & $\geq 60$ \\
\hline
\end{tabular}

Berdasarkan Tabel 1 di atas bahwa kompetensi tenaga administrasi sekolah di SMA Negeri seKabupaten Trenggalek berada dalam kategori tinggi. Kepala TAS memperoleh skor rata-rata 193,75. Rata-rata tersebut kedudukannya lebih dari sama dengan 186, jadi dapat dikatan kompetensi kepala TAS dalam kategori tinggi. Pelaksana urusan memperoleh skor rata-rata 157,92. Rata-rata tersebut kedudukannya lebih dari sama dengan 150, jadi dapat dikatakan kompetensi pelaksana urusan dalam kategori tinggi. Tenaga layanan khusus memperoleh skor rata-rata 158,14. Rata-rata tersebut kedudukannya lebihdari sama dengan 150, jadi dapat dikatakan kompetensi tenaga layanan khusus berada dalam kategori tinggi.

Skor rata-rata variabel motivasi kerja sebesar 105,60. Rata-rata tersebut kedudukannya lebih dari sama dengan 99, jadi dapat dikatakan motivasi kerja tenaga administrasi di SMA Negeri se-Kabupaten Trenggalek dalam sekolah berada dalam kategori tinggi.

Skor rata-rata variabel kinerja sebesar 65,04. Rata-rata tersebut kedudukannya lebih dari sama dengan 60, jadi dapat dikatakan kinerja tenaga administrasi sekolah berada di SMA Negeri se-Kabupaten Trenggalek dalam kategori tinggi.

\section{Pengujian Hipotesis}

\section{Analisis Uji Korelasi Product Moment Person}

Dalam penelitian ini, untuk mengetahui seberapa besar hubungan antara variabel bebas (Y) dan variabel terikat (Y). Hasil statistik uji product moment person dapat dilihat pada Tabel 2 berikut.

Tabel 2 Hasil Analisis Korelasi

Correlations

\begin{tabular}{ccccc}
\hline & & Kinerja & Kompetensi & Motivasi \\
\hline Pearson & Kinerja & $\mathbf{1 . 0 0 0}$ & .736 & .957 \\
Correlation & Kompetensi & .736 & 1.000 & .730 \\
& Motivasi & .957 & .730 & 1.000 \\
Sig. (1-tailed) & Kinerja & & .000 & .000 \\
& Kompetensi & .000 & & .000 \\
& Motivasi & .000 & .000 & \\
$\mathrm{~N}$ & Kinerja & 111 & 111 & 111 \\
& Kompetensi & 111 & 111 & 111 \\
& Motivasi & 111 & 111 & 111 \\
\hline
\end{tabular}

Sampel yang digunakan sebanyak 111 responden, dari sini didapat nilai $\mathrm{df}=\mathrm{n}-2=111-2=109$. Sehingga rtabel product moment pada signifikansi 5\%, didapatkan angka rtabel $=0,195$. Berdasarkan 
Tabel 2 di atas menunjukkan bahwa: 1. diperoleh rhitung sebesar 0,736 dan nilai signifikansi 0,000 . Skor rhitung $>$ rtabel $(0,736>0,195)$ dan nilai signifikansinya lebih kecil dari $0,05(0,000<0,05)$, sehingga $\mathrm{H} 0$ ditolak dan H1diterima. Artinya ada hubungan antara kompetensi dan kinerja TAS di SMA Negeri se-Kabupaten Trenggalek; 2 . diperoleh rhitung sebesar 0,957 dan nilai signifikansi 0,000 . Skor rhitung $>$ rtabel $(0,957>0,195)$ dan nilai signifikansinya lebih kecil dari $0,05(0,000<0,05)$, sehingga H0 ditolak dan H1diterima. Artinya ada hubungan antara motivasi kerja dan kinerja TAS di SMA Negeri se-Kabupaten Trenggalek.

\section{Analisis Korelasi Ganda (Multiple Correlation)}

Analisis korelasi ganda dalam penelitian ini untuk mengetahui hubungan pada ketiga variabel secara bersama-sama. Hasil statistik analisis korelasi ganda dapat dilihat pada Tabel 3 berikut.

Tabel 3 Hasil Perhitungan Korelasi Ganda

\begin{tabular}{|c|c|c|c|c|c|c|c|c|c|}
\hline & \multirow[b]{3}{*}{$\mathbf{R}$} & \multirow[b]{3}{*}{$\begin{array}{c}\mathbf{R} \\
\text { Square }\end{array}$} & \multirow[b]{3}{*}{$\begin{array}{l}\text { Adjusted } \\
\text { R Square }\end{array}$} & \multicolumn{6}{|c|}{ Model Summaryb } \\
\hline \multirow[b]{2}{*}{ Model } & & & & & \multicolumn{5}{|c|}{ Change Statistics } \\
\hline & & & & $\begin{array}{l}\text { Std. Error of } \\
\text { the Estimate }\end{array}$ & & $\begin{array}{c}\mathbf{F} \\
\text { Change }\end{array}$ & df1 & df2 & $\begin{array}{l}\text { Sig. F } \\
\text { Change }\end{array}$ \\
\hline 1 & $.959 a$ & .920 & .918 & 1.406 & .920 & 618.849 & 2 & 108 & .000 \\
\hline
\end{tabular}

a. Predictors: (Constant), Motivasi, Kompetensi

b. Dependent Variable: Kinerja

Berdasarkan Tabel 3 di atas, diperoleh nilai Fhitung sebesar 618.849 dengan nilai signifikansi 0,000. Nilai Fhitung $(618.849)>$ Ftabel $(3,08)$, dan nilai signifikansi lebih kecil dari nilai probabilitas 0,05 atau nilai $0,000<0,05$. Maka $\mathrm{H} 0$ ditolak dan $\mathrm{H} 1$ dierima, artinya ada hubungan yang positif sehingga terjadi hubungan yang signifikan antara kompetensi dan motivasi kerja dengan kinerja tenaga administrasi sekolah di SMA Negeri se-Kabupaten Trenggalek.

\section{PEMBAHASAN}

\section{Kompetensi Tenaga Administrasi Sekolah}

Berdasarkan hasil analisis deskriptif, menunjukkan bahwa kompetensi kepala TAS, pelaksana urusan dan tenaga layanan khusus berada pada kategori tinggi. Pernyataan tersebut dibuktikan dari hasil penelitian yang menunjukkan nilai mean pada kepala TAS sebesar 193,75 yang berada dalam interval 186-248 dan tergolong dalam kategori tinggi. Selanjunya nilai mean pada pelaksana urusan sebesar 157,92 yang berada dalam interval 150-200 dan tegolong dalam kategori tinggi. Kemudian nilai mean pada tenaga layanan khusus sebesar 158,14 yang berada dalam interval 150-200 dan tergolong dalam kategori tinggi. Kompetensi yang dimiliki oleh TAS di SMA Negeri se-Kabupaten Trenggalek termasuk dalam kategori tinggi, hal ini sesuai dengan Permendiknas Nomor 24 Tahun 2008 tentang standar Tenaga Administrasi Sekolah/Madrasah (TAS/ M), dimensi kompetensi yang harus dimiliki oleh Kepala TAS adalah kompetensi kepribadian, kompetensi sosial, kompetensi teknis, dan kompetensi manajerial. Dimensi kompetensi yang dimiliki oleh pelaksana urusan dan petugas layanan khusus adalah kompetensi kepribadian, kompetensi sosial, dan kompetensi teknis.

\section{Motivasi Kerja Tenaga Administrasi Sekolah}

Berdasarkan hasil analisis deskriptif, menunjukkan bahwa motivasi kerja TAS di SMAN seKabupaten Trenggalek berada dalam kategori tinggi. Pernyataan tersebut dapat dibuktikan dari hasil penelitian yang menunjukkan nilai mean pada motivasi kerja TAS sebesar 105,60 yang berada dalam interval 99-132 dan tergolong dalam kategori tinggi. Hal ini sejalan dengan pendapat Siagian (2007:287), bahwa motivasi merupakan "dorongan dalam diri karyawan untuk berbuat semaksimal mungkin dalam melaksanakan tugasnya". Terdapat dua faktor besar yang mempengaruhi motivasi seseorang. Menurut Herzberg (Hasibuan, 2010), dua faktor yang mempengaruhi motivasi adalah sebagai berikut. Faktor motivator (intrinsik) dan faktor hygine (ekstrinsik). Yang dimaksud faktor motivator adalah hal-hal yang 
mendorong berprestasi yang sifatnya intrinsik, yang berarti berasal dari dalam diri seseorang, sedangkan yang dimaksud dengan faktor hygiene atau pemeliharaan adalah faktor-faktor yang sifatnya ekstrinsik yang berarti berasal dari luar diri seseorang yang turut menentukan perilaku seseorang dalam kehidupan seseorang.

\section{Kinerja Tenaga Administrasi Sekolah}

Berdasarkan hasil analisis deskriptif, menunjukkan bahwa kinerja TAS di SMAN se-Kabupaten Trenggalek berada dalam kategori tinggi. Pernyataan tersebut dapat dibuktikan dari hasil penelitian yang menunjukkan nilai mean pada kinerja TAS sebesar 65,04 yang berada dalam interval 60-80 dan tergolong dalam kategori tinggi. Hal ini sejalan dengan pendapat Mathis dan Jackson (Umam, 2010), faktor- faktor yang mempengaruhi kinerja adalah "kompetensi, motivasi, dukungan yang diterima, keberadaan pekerjaan yang mereka lakukan, dan hubungan mereka dengan organisasi". Menurut Gibson (Umam, 2010) ada tiga faktor yang mempengaruhi kinerja, yaitu: 1. faktor individu: kompetensi, keterampilan, latar belakang keluarga, pengalaman kerja, tingkat sosial, dan demografi seseorang; 2 . faktor psikologi: persepsi, peran, sikap, kepribadian, motivasi, dan kepuasan kerja; 3 . faktor organisasi: struktur organisasi, desain pekerjaan, kepemimpinan, sistem penghargaan (reward system).

\section{Hubungan Kompetensi dengan Kinerja Tenaga Administrasi Sekolah}

Berdasarkan hasil pengujian dengan menggunakan Product Moment Pearson menunjukkan bahwa ada hubungan antara variabel kompetensi (X1) dengan variabel kinerja (Y) di SMAN se-Kabupaten Trenggalek. Hal ini sejalan dengan pendapat Grote (Pramudyo, 2010:35), "kompetensi dapat digunakan untuk memprediksi kinerja, yaitu siapa yang berkinerja baik dan kurang baik tergantung pada kompetensi yang dimilikinya, diukur dari kriteria atau standar yang digunakan”. Menurut Sandberg (Dewi, 2005:52), "kompetensi dipandang sebagai atribut yang spesifik, seperti pengetahuan dan keterampilan yang digunakan untuk menunjukkan suatu kinerja dalam suatu pekerjaan yang sedang dilakukan".

\section{Hubungan Motivasi Kerja dengan Kinerja Tenaga Administrasi Sekolah}

Berdasarkan hasil pengujian dengan menggunakan Product Moment Pearson menunjukkan bahwa ada hubungan antara variabel motivasi kerja (X2) dengan variabel produktivitas kerja (Y) di SMAN se-Kabupaten Trenggalek. Hal ini sejalan dengan pendapat Rivai (2009:837) mengatakan bahwa: motivasi adalah serangkaian sikap dan nilai-nilai yang mempengaruhi individu untuk mencapai hal yang spesifikasi sesuai dengan tujuan individu. Sikap dan nilai tersebut merupakan suatu yang invisible yang memberikan kekuatan untuk mendorong individu bertingkah laku dalam mencapai tujuan. Dorongan tersebut terdiri dari komponen, yaitu: arah perilaku (kerja untuk mencapai tujuan), dan kekuatan perilaku (seberapa kuat usaha individu dalam bekerja).

Menurut Nawawi (2003:112) motivasi adalah "suasana batin atau psikologi seorang pekerja sebagai individu dalam masyarakat, organisasi atau perusahaan dalam lingkungan kerjanya, sangat berpengaruh pada pelaksanaan pekerjaannya".

\section{Hubungan Kompetensi dan Motivasi Kerja dengan Kinerja Tenaga Administrasi Sekolah}

Berdasarkan hasil penelitian menggunakan rumus korelasi ganda (multiple correlation) menunjukkan bahwa ada hubungan antara kompetensi dan motivasi kerja dengan kinerja TAS di SMAN se-Kabupaten Trenggalek. Hasil penelitian ini sesuai dengan penelitian yang dilakukan oleh Murdlhiyanah (2014) yang berjudul Hubungan Antara Kompetensi Dan Motivasi Kerja dengan Kinerja Pegawai di Kantor Kementerian Agama Kabupaten Pasuruan, memberikan hasil yang menyatakan bahwa "variabel kompetensi dan motivasi kerja secara simultan berhubungan positif terhadap kinerja pegawai Kantor Kementerian Agama Kabupaten Pasuruan". Menurut Siagian (2004:171), “faktor-faktor motivasional memiliki dua sifat. Adapun dua sifat tersebut yaitu: 1) bersifat Intrinsik: Kemajuan, tanggungjawab dan kompetensi, dan 2) bersifat Ekstrinsik: Upah atau gaji yang besar, promosi, hubungan yang baik dengan atasan dan kondisi kerja yang menyenangkan". Motivasi kerja seseorang terbentuk berdasarkan dua faktor, yaitu faktor instrinsik dan faktor ekstrinsik yang masing-masing dapat mempengaruhi tingkat kinerja pegawai. Wibowo (2013) mengatakan bahwa kinerja merupakan "implementasi dari perancanaan 
yang telah disusun tersebut. Implementasi kinerja dilakukan oleh sumber daya manusia yang memiliki kompetensi, motivasi dan kepentingan".

\section{KESIMPULAN DAN SARAN}

\section{Kesimpulan}

Berdasarkan hasil penelitian dan hasil pembahasan dalam penelitian ini, dapat diperoleh kesimpulan sebagai berikut: (1) Tingkat kompetensi tenaga administrasi sekolah di SMA Negeri se-Kabupaten Trenggalek berada dalam kategori tinggi, (2) Tingkat motivasi kerja tenaga administrasi sekolah di SMA Negeri se-Kabupaten Trenggalek berada dalam kategori tinggi, (3) Tingkat kinerja tenaga administrasi sekolah di SMA Negeri se-Kabupaten Trenggalek berada dalam kategori tinggi, (4) Terdapat hubungan yang signifikan antara kompetensi dan kinerja tenaga administrasi sekolah di SMA Negeri se-Kabupaten Trenggalek, (5) Terdapat hubungan yang signifikan antara motivasi kerja dan kinerja tenaga administrasi sekolah di SMA Negeri se-Kabupaten Trenggalek, dan (6) Secara simultan terdapat hubungan yang sangat kuat antara kompetensi, motivasi kerja, dan kinerja tenaga administrasi sekolah di SMA Negeri se-Kabupaten Trenggalek. Artinya tinggi rendahnya tingkat kompetensi dan motivasi kerja berkorelasi signifikan dengan kinerja tenaga administrasi sekolah.

\section{Saran}

Berdasarkan hasil penelitian dan hasil pembahasan dalam penelitian ini, peneliti memberikan saran sebagai berikut: (1) Kepala SMAN se-Kabupaten Trenggalek, diharapkan memperhatikan perkembangan kompetensi dan meningkatkannya dalam memberikan layanan administrasi sekolah kepada siswa dan anggota lainnya, (2) Tenaga Administrasi Sekolah SMAN se-Kabupaten Trenggalek, disaranka hasil penelitian ini dapat dijadikan sebagai bahan masukan untuk mengevaluasi dan meningkatkan kompetensi yang dimiliki TAS meliputi kompetensi kepribadian, kompetensi sosial, kompetensi teknik, serta kompetensi manajerial kepala TAS, (3) Ketua Jurusan Administrasi Pendidikan, disarankan hasil penelitian dapat dijadikan sebagai bahan untuk memperkaya kajian untuk matakuliah manajemen sumber daya manusia khususnya tentang hubungan antara kompetensi dan motivasi kerja dengan kinerja kerja tenaga administrasi sekolah, (4) Mahasiswa Jurusan Administrasi Pendidikan, diharapkan hasil penelitian ini dapat dijadikan sebagai bahan belajar mahasiswa administrasi pendidikan pada matakuliah manajemen sumber daya manusia, dan (5) Peneliti lain, disarankan apabila ingin melakukan penelitian yang sejenis, dengan fokus pada variabel lain yang berkaitan dengan kinerja TAS. Sehingga diperoleh hasil penelitian yang lebih komprehensif.

\section{DAFTAR RUJUKAN}

Dewi, S.W.K, dkk. 2005. Telaah Hubungan Kompetensi, Motivasi dan Kinerja Karyawan. Bandung: BSI.

Dwidiyaningsih, Y. 2011. Pengaruh Kinerja Pegawai Tata Usaha Terhadap Layanan Adminstrasi Di SMA Negeri Se-Kecamatan Sukatani Kabupaten Bekasi. Bandung: Administrasi Pendidikan FIP UPI.

Hasibuan, M.S.P. 2010. Organisasi dan Motivasi: Dasar Peningkatan Produktivitas. Jakarta: PT. Bumi Aksara.

Mangkunegara, A.P. 2003. Perencanaan dan Pengembangan Sumber Daya Manusia. Bandung: Refika Aditama.

Mantja, W. 2007. Etnografi; Desain Penelitian Kualitatif Pendidikan dan Manajemen Pendidikan. Malang: Elang Mas.

Murdlhiyah, N.A. 2014. Hubungan antara Kompetensi dan Motivasi Kerja dengan Kinerja Pegawai di Kantor Kementerian Agama Kabupaten Pasuruan. Surabaya: UIN Sunan Ampel Surabaya.

Nawawi, H. 2003. Manajemen Sumber Daya Manusia untuk Bisnis yangKompetetif. Yogyakarta: Gajah Mada University Press.

Nugraha, D.A. 2013. Hubungan antara Kompetensi Kerja dengan Kinerja Karyawan PT. bukit Asam (Persero) Tbk. Surakarta: Fakultas Psikologi Universitas Muhammaditah Surakarta.

Peraturan Menteri Pendidikan Nasional Republik Indonesia Nomor 24 Tahun 2008 tentang Standar Tenaga Administrasi Sekolah/Madrasah, (Online), (http://luk.staff.ugm.ac.id/atur/bsnp/Permendiknas242008StandarTenagaAdministrasiSekolah.pdf), diakses 31 Januari 2017. 
Pramudyo, A. 2010. Analisis Faktor-faktor yang Mempengaruhi Kinerja Dosen Negeri Dipekerjakan Pada Kopertis Wilayah V Yogyakarta. Yogyakarta: JBTI

Rahmawati. D. 2008. Hubungan Motivasi Kerja dengan Kinerja Tenaga Administrasi Sekolah (TAS) pada SMA Negeri di Kota Malang. Malang: AP FIP UM.

Rivai, V. 2009. Manajemen Sumber Daya Manusia untuk Perusahaan dari Teori ke Praktik. Jakarta: Raja Grafindo Persada.

Rucky, A.S. 2003. Sistem Manajemen Kinerja. Jakarta: Gramedia Pustaka.

Sedarmayanti. 2009. Sumber Daya Manusia dan Produktivitas Kerja. Bandung: CV Manda Maju.

Siagian, S.P. 2004. Manajemen Sumber Daya Manusia. Jakarta: Bumi Aksara.

Siagian, S.P. 2007. Teori Motivasi dan Aplikasi. Jakarta: Penerbit Salemba Empat.

Umam, K. 2010. Perilaku Organisasi. Bandung: CV. Pustaka Setia.

Wibowo, A. 2013. Manajemen Pendidikan Karakter di Sekolah. Yogyakarta: Pustaka Pelajar. 